\title{
下顎枝矢状分割法術後の知覚障害に関する臨床的研究
}

\author{
藤川真紀・野間弘康・高崎義人

\section{Clinical studies of neurosensory disturbance after sagittal splitting ramus osteotomy}

\author{
Maki Fujikawa $\cdot$ Hiroyasu Noma $\cdot$ Yoshito Takasaki
}

\begin{abstract}
Sagittal splitting ramus osteotomy (SSRO) is the most common orthodontic procedure used to correct mandibular deformation. However there is a postoperative risk of neurosensory disturbance (NSD) of the mental nerve.

A total of 84 patients underwent preoperative and postoperative bilateral examinations (total: 168 examinations). Subjective symptoms were assessed by interview, and constant-touch was evaluated by tactile-threshold tests with the use of a Semmes-Weinstein pressure aesthesiometer (SW test) and by static two-point discrimination tests ( 2 PD). Dynamic-touch was examined by vibratory sensibility tests.

No significant differences were observed as compared with the preoperative scores on the SW test after 4 weeks. Furthermore, no change in the mean preoperative value on the 2 PD test was observed at the 8 th postoperative week. A significant difference was detected between the preoperative score on the vibratory sensation test and the score after 24 weeks. Dynamic-touch assessment suggested that recovery was slow as compared with constant-touch recovery. The majority of patients scored 1.65 (the smallest sensible filament) on the SW test, and $83.2 \%$ of these patients showed an improvement in symptoms. A significant difference was noted between symptoms and the dispersion of vibratory sensibility test scores. The vibratory sensibility test could detect sensation recovery by slow regeneration of nerves, but the probability of not detecting sensation was high when only the SW test was used.
\end{abstract}

Sensibility occurs via the function of various sensory units. Thus, a combination of tests should be performed to assess sensiblity associated with perceptual disorders.

Key words: sagittal splitting ramus osteotomy (下顎枝矢状分割法), neurosensory disturbance（知覚障害), tactile-threshold test (触圧覚検査), static two-point discrimination test (静的 2 点識別闇検査), vibratory sensibility test（振動覚検査）

緒

言

下顎枝矢状分割法は下顎枝を矢状面で内外側に分割して 下顎骨体を目的の位置に移動し固定する手術である ${ }^{1)}$.こ の術式は口内法であること, 骨の接触面積が広いこと, 移 動距離や移動範囲の許容範囲が大きいことなどの利点があ るため, 顎変形症の外科的矯正手術において今日最も多く

東京歯科大学口腔外科学第一講座

(主任 : 野間弘康)

The First Department of Oral and Maxillofacial Surgery, Tokyo Dental College (Chief: Prof. Hiroyasu Noma)

受付日：平成13年 3 月 19 日
用いられている術式である ${ }^{1)}$. しかしながら反面, 術後の オトガイ神経支配領域の知覚障害が生じることがあるとい う欠点が指摘される 2 14).

従来より下顎枝矢状分割法術後のオトガイ神経知覚障害 を観察した報告は多くみられるが2 14)，これらの報告は知 覚障害を定性的に評価したものであったり $\left.{ }^{8}, 9\right)$, 触覚や圧 覚の一部だけを観察しているものが多い3，4,10,11).そのた め, 検査結果と実際に患者が訴える自覚症状との間に相違 があり，これが臨床上大きなトラブルの原因となっている. 感覚はいろいろな種類の感覚単位により構成されているの で15 22), 知覚障害について観察する際には単一の感覚の評 価のみではなく, いくつかの異なった感覚についての検査 
法を組み合わせて行う必要がある.

そこで, 今回著者らは下顎枝矢状分割法を施行した患者 に対し, 遅順応性感覚単位の 1 つである静的触覚の検査と して SW 知覚テスターによる触圧覚検査を, 静的触覚の神 経支配分布密度の検査として静的 2 点識別間検査を行った 15). また, 速順応性感覚単位の 1 つである動的触覚の検査 として振動覚検査を行った ${ }^{15)}$. そしてさらに, その結果を 同時に聴取した自覚症状と比較することによって，下顎枝 矢状分割法術後に生じる知覚障害の実態と, その後の静的 触覚, 動的触覚の回復状態を観察した.

\section{研究方 法}

\section{1. 対象}

東京歯科大学口腔外科学第一講座 (以下当講座と略す)

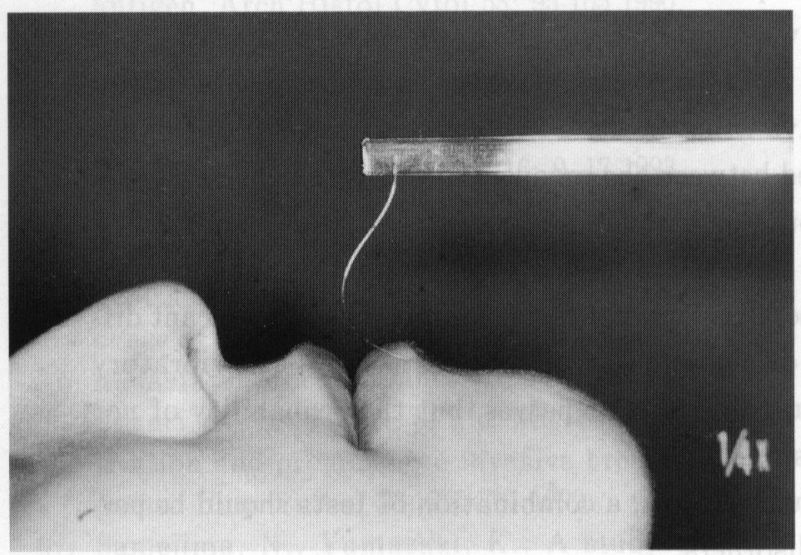

写真 1 触圧覚検査 (SW test) SW 知覚テスターを用いた.
で1996年 7 月から1999年 8 月までに下顎枝矢状分割法（以 下SSRO と略す）を施行した178名のうち, 術前・術後に 知覚検査を施行しえた84名168側（男性40名, 女性44名, 年 齢 $24 \pm 5$ 歳) を対象とした. 内訳は, SSRO 単独が44名（男 性13名, 女性31名), Le Fort I 型骨切り術+SSRO が40名 （男性27名，女性13名）であった.なおこれら全症例に対 し術中にステロイド剤の投与と, 術後に自覚症状の訴えの あった場合はビタミン $\mathrm{B}_{12}$ 製剤と ATP 製剤の投与を行っ た。

\section{2. 観察時期}

各検査ならびに自覚症状の聴取を, 手術前, 手術 $1,4,8$, 12,24週後に行った。

\section{3 . 測定方法および測定部位}

1 ) 触圧覚検査 (以下, SW test とする)

静的触覚を観察するための SW testには SemmesWeinstein pressure aesthesiometer (以下 SW 知覚テス ターと略す) を用いた。これは, von Freyの触毛による検 査の進展型で, 種々の太さのナイロンモノフィラメントを 皮膚表面に圧接して触圧覚の障害の程度を測定するもので ある ${ }^{23 \sim 25)}$. SW 知覚テスターは簡便で知覚障害の程度を把 握しやすいため, 整形外科領域などで広く使われており ${ }^{23)}$, 特に近年では口腔外科領域においても SW test が広く行 われるようになった2〜4,6,7，12,13,26).

SW 知覚テスターは, 最も細いフィラメントによる0.0045g

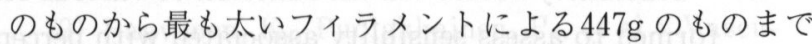
20段階の力を加えることができる20本のテスターから構成 されている.この皮膚に及ぼす力を対数に換算した值が

表 1 Bell の評価基準

\begin{tabular}{|c|c|c|c|}
\hline & & Manufacturer's marking & Calculated stress $\left(\mathrm{gf} / \mathrm{mm}^{2}\right)$ \\
\hline Level 5 & 触 知不能 & 6.65触知不能 & 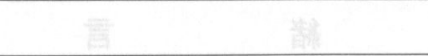 \\
\hline Level 4 & 保護的感覚の脱失 & $\begin{array}{l}6.65 \\
? \\
4.56\end{array}$ & $\begin{array}{c}439 \\
? \\
47.3\end{array}$ \\
\hline Level 3 & 保護的感覚の低下 & 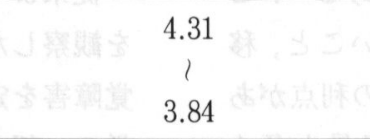 & $\begin{array}{c}33.1 \\
? \\
19.3\end{array}$ \\
\hline Level 2 & Light touch の低下 & 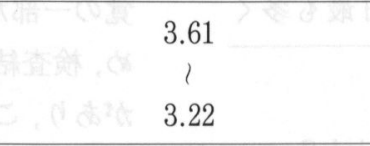 & $\begin{array}{c}17.7 \\
\text { ? } \\
11.1\end{array}$ \\
\hline Level 1 & 正 常 域 & 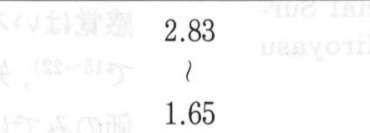 & $\begin{array}{c}4.86 \\
1 \\
1.45\end{array}$ \\
\hline
\end{tabular}




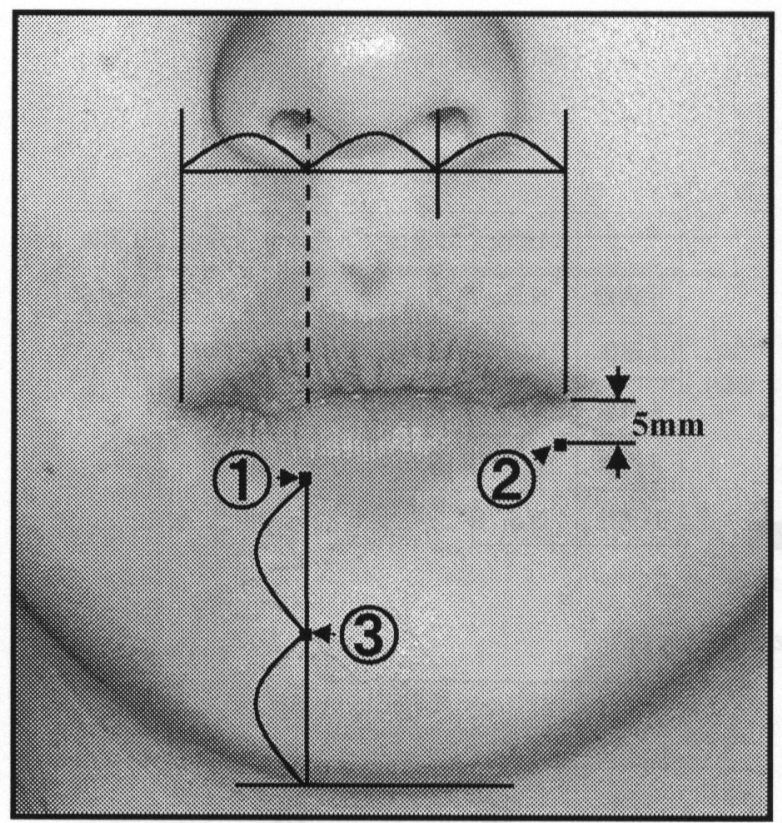

写真 2 測定部位

(1)下唇枝 : 左右口角間を 3 等分した赤唇移行部

(2)口角枝 : 口角より $5 \mathrm{~mm}$ 下方

(3)オトガイ枝 : 下唇枝の測定点よりオトガイ下端に下ろ した垂線の中点

マーキングナンバーとして個々のテスターに印記されてい る.

検査は, 被験者を水平位にし閉眼させた後に, Werner の 方法 ${ }^{25)} に$ 準じ測定部位にテスターを 1 ～1.5秒かけて垂直 に下ろし, フィラメントが軽く屈曲する程度の圧を加え, 1 〜 1.5秒かけて離した. マーキングナンバー1.65４.08の範 囲のテスターでは 1 つの測定点に対し 3 回の刺激を行い, 4.17〜6.65の範囲のテスターでは 1 回の刺激を行った（写 真 1 ). また測定は最小值のマーキングナンバー1.65より開 始し, 患者が識別できるまで順次テスターの段階を上げ, 最初に患者が触知できたテスターのナンバーを計測值とし た. また, 得られた值はLevinの圧の計算值 ${ }^{24)} に$ 変換し, 統計処理を行った.さらに知覚障害の程度を把握するため, この計測值を Bell の評価基準 ${ }^{23)} に$ 従って 5 段階に等級づ けた（表1).

測定部位は，オトガイ神経の走行を考慮して ${ }^{28)}$ 下唇枝 (左右口角間を 3 等分した赤唇移行部), 口角枝 (口角より 5 $\mathrm{mm}$ 下方), オトガイ枝 (下唇枝の測定点よりオトガイ下端 に下ろした垂線の中点) の 3 点とした ${ }^{26,27)}$ (写真 2 ).

2 ) 静的 2 点識閾別検査 (以下 2 PD とする)

$2 \mathrm{PD}$ は静的触覚の神経支配分布密度を観察するもので あり ${ }^{15,17)}$, 知覚検査用ノギスを用いて行った。

測定部位は左右オトガイ部皮虞で, SW testでのオトガ

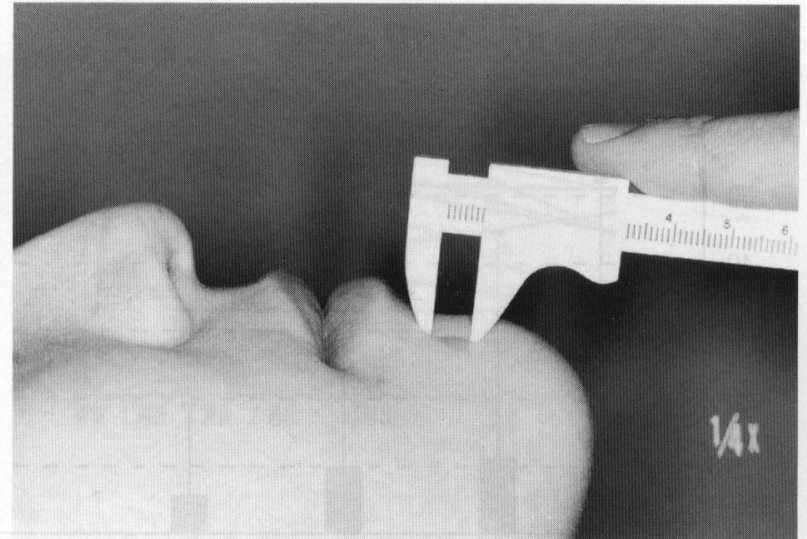

写真 3 静的 2 点識別閾検査 ( 2 PD) 知覚検査用ノギスを用いた。

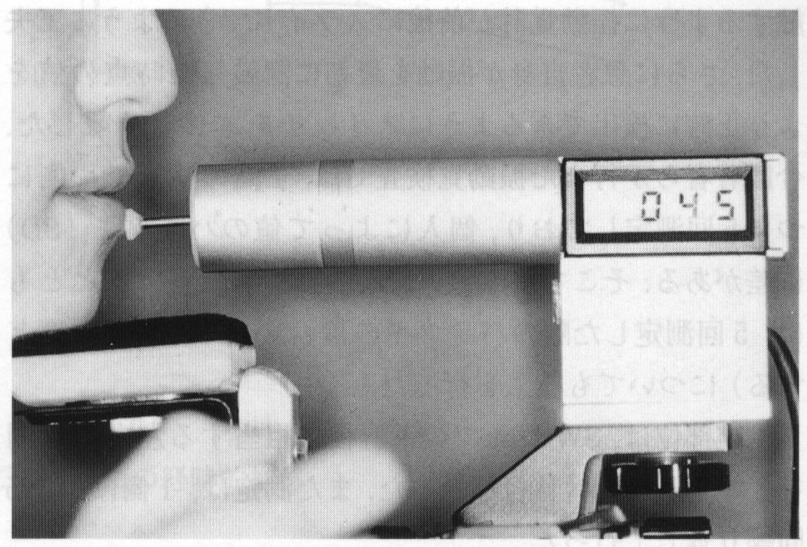

写真 4 振動覚検查

SMV- 5 型振動覚計を用いた.

イ枝を中心に縦方向に徐々に広げ測定した（写真 3 ).

3 ) 振動覚検査

動的触覚の 1 つである振動覚を観察するために SMV- 5 型振動覚計 (テク)ローグ社製：東京, 以下 SMV- 5 とす る）を用いて振動覚検査を行った（写真 4 ). SMV-5 は, 鈴木・松岡らが1989年に開発したSMV-1に改良が加えら れ，1991年より当科で使用しているもので29 31), 他の振動 覚計に比べ閾值測定の信頼度が高いといわれている これは, 振動数を $200 \mathrm{~Hz}$ に固定し, 振幅を増幅させ, 患者が 振動を感じた時点の值を振動覚の単位である加速度として 検出するものである ${ }^{31)}$. 当機器は, 糖尿病性神経障害や手 指の知覚障害での振動覚閾值の測定に広く用いられてい $3^{29-33)}$

この SMV-5 をロ腔外科領域に応用するため当講座にお いて改良した点は2），まず測定点に固定できるように，振 動覚計を三脚に設置し固定した. 次に測定点が無圧的に接 


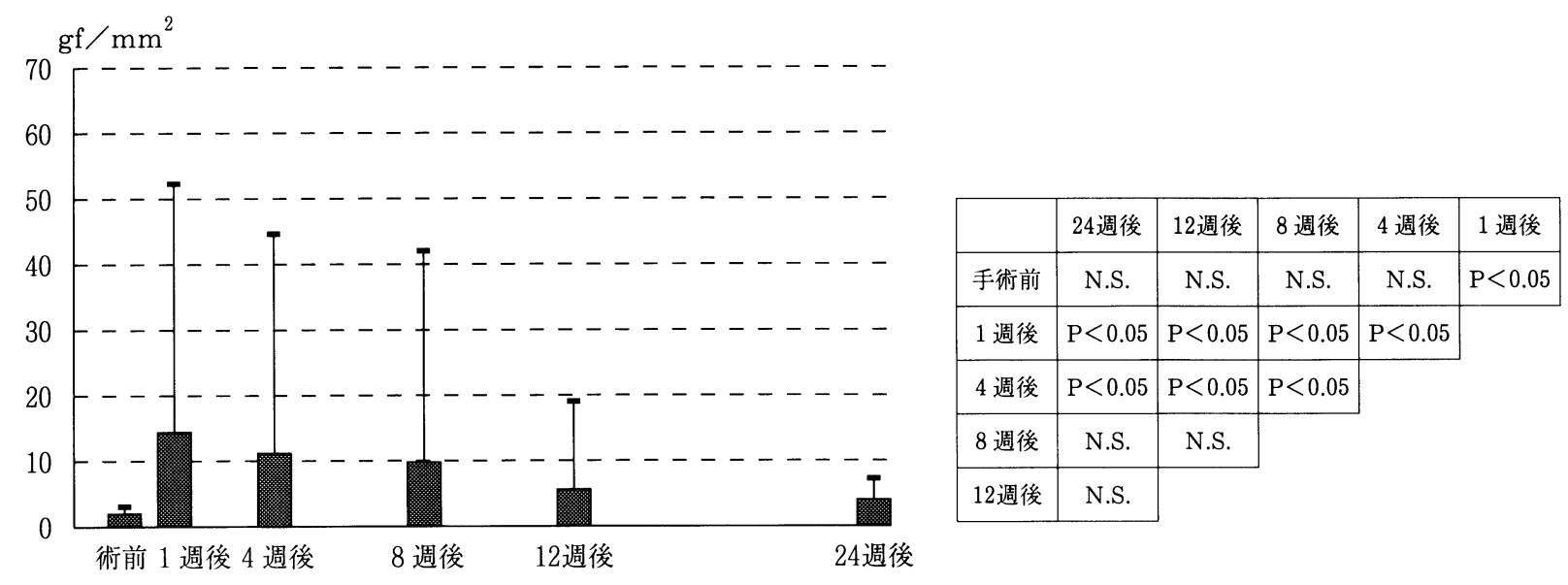

図 $1 \mathrm{SW}$ test での平均值の推移

触するように振動覚計が前後にスライドできるように工夫 した.さらに患者自身が振動を最初に認識した時点の值を より正確に検出できるようにスイッチを本体と分離した. 今回著者らが行った振動覚検査では, 1 回の検査で片側に つき 5 回測定しており，個人によって值のバラッキ $(\mathrm{SD})$ に差がある.そこで平均值の経時的推移を観察するととも に, 5 回測定した際のバラッキの度合い（以下, 散布度と する）についても検索を行った.

測定部位は, SW test での下唇枝に相当する左右口角間 を 3 等分した赤唇移行部とした. また測定は，1 側につき 5 回繰り返して行った。

4 ) 自覚症状の聴取

聴取した自覚症状はまず全く感覚のない知覚脱失から感 覚の回復過程で現れる異感覚, 錯感覚, 知覚鈍麻の 4 段階 に分類したうえで35)，これらの症状のどれかを有するもの を「自覚症状あり」, 全く認めないものを「自覚症状なし」 とした.

対象とする部位はオトガイ神経支配領域とした.

また, 自覚症状の有無と各検査值との関係を検索した.

\section{4. 統計学的解析方法}

SW test，2 PD，振動覚検査でそれぞれ得られた値の平 均值の経時的推移については, ノンパラメトリック法のう ち対応したデー夕の差を比較するため, 有意水準 $0.05 に て ~$ Wilcoxonの符号付順位検定を行った．振動覚検查での散 布度の経時的推移については有意水準 0.05 で Kolmogorov-Smirnov の 2 標本検定を行った. 自覚症状の 経時的推移については $\chi^{2}$ 検定を行った，さらに自覚症状 と散布度との関係についても $\chi^{2}$ 検定で統計処理を行った。
結果

\section{SW test}

まず, SW test での平均值の経時的変化について観察を

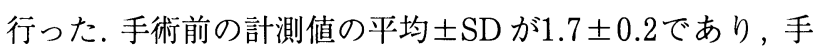
術 $1 ， 4 ， 8 ， 12 ， 24$ 週後の值はそれぞれ $2.4 \pm 1.2,2.2 \pm 1.1$, $2.1 \pm 0.9,1.9 \pm 0.7,1.8 \pm 0.5$ であった。この SW test で計 測された值を圧值に換算すると ${ }^{24)}$, 手術前, 手術 $1 ， 4 ， 8$, 12,24週後の值はそれぞれ $1.6 \pm 0.8,13.9 \pm 38.7,10.7 \pm 33.5$, $9.8 \pm 32.5,5.2 \pm 13.5,2.8 \pm 4.9 \mathrm{gf} / \mathrm{mm}^{2}$ であった. 術前の 值に比べて手術 1 週後では統計学的有意差を認めていたも のの, 手術 4 週後以降では有意差は認められなかった（図 1 ).

次に, 手術 1 週後の值について Bell の評価基準に基づき 分類したところ, Level 1 が137側, Level 2 が 2 側, Level 3 が 8 側, Level 4 が18側, Level 5 が 3 側であった. 各グ ループごとの経時的変化を観察したところ, Level 2 の 2 側は，手術12週後には術前值にまで回復していたが，これ より高度な知覚障害を認めた Level $3 \sim 5$ では手術 24 週後 に扔いても術前までの回復を認めなかった（図 2 ).

\section{2. $2 \mathrm{PD}$}

$2 \mathrm{PD}$ での平均值の経時的変化を観察したところ, 手術 前の平均值は $7.7 \pm 2.9 \mathrm{~mm}$ で手術 $1,4,8,12,24$ 週後は それぞれ $12.1 \pm 5.5,9.6 \pm 4.8,8.7 \pm 4.7,8.1 \pm 4.1,8.1 \pm 3.6$ $\mathrm{mm}$ であり, 術前の值に比べて手術 1,4 週後では統計学 的有意差があったものの， $8,12,24$ 週後では有意差はみら れなかった（図 3 ).

なお，2 PD で測定範囲を超え，測定不能であったものは $20 / 168$ 側 $(11.9 \%)$ で, このなかで Level $2 \sim 5$ のものは $10 / 20$ 側 $(50.0 \%)$ であった. 


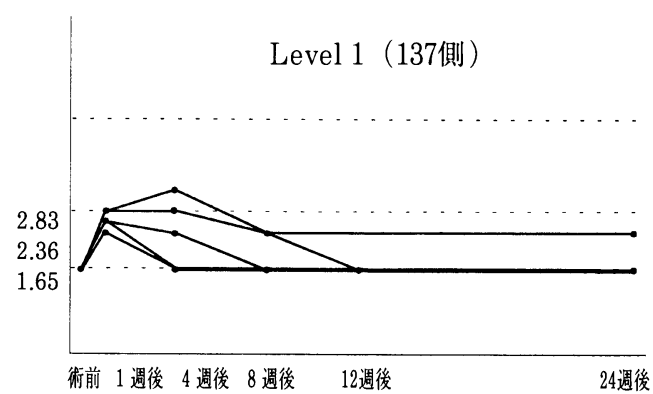

Level 2（2 側）

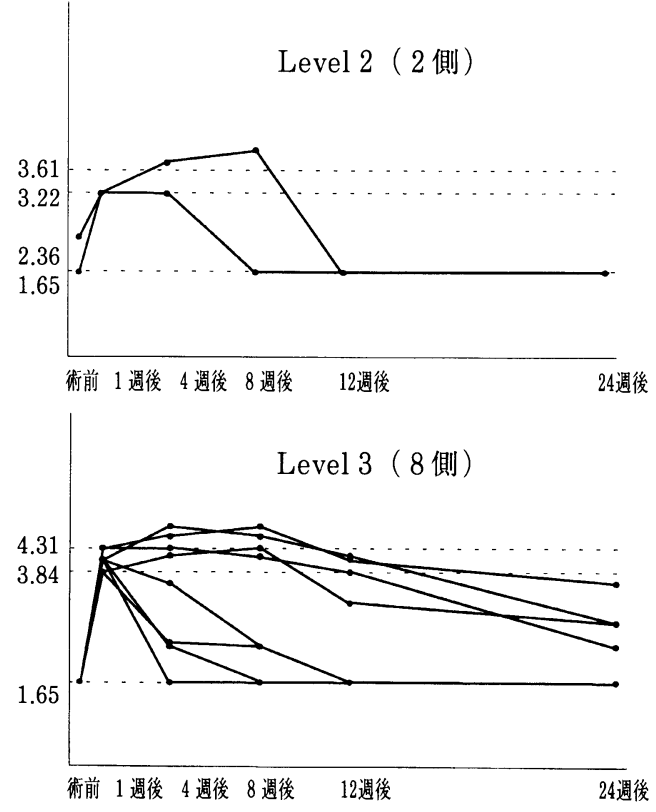

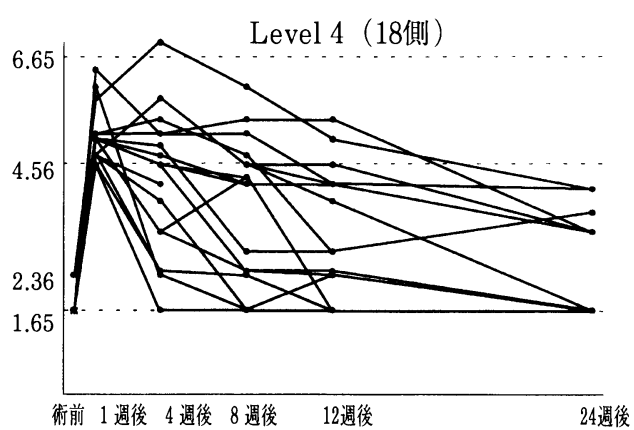

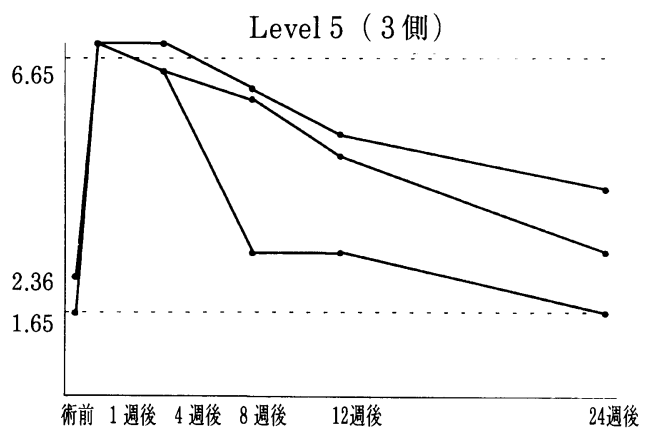

図 $2 \mathrm{SW}$ test でのグループごとの閾值の経時的推移

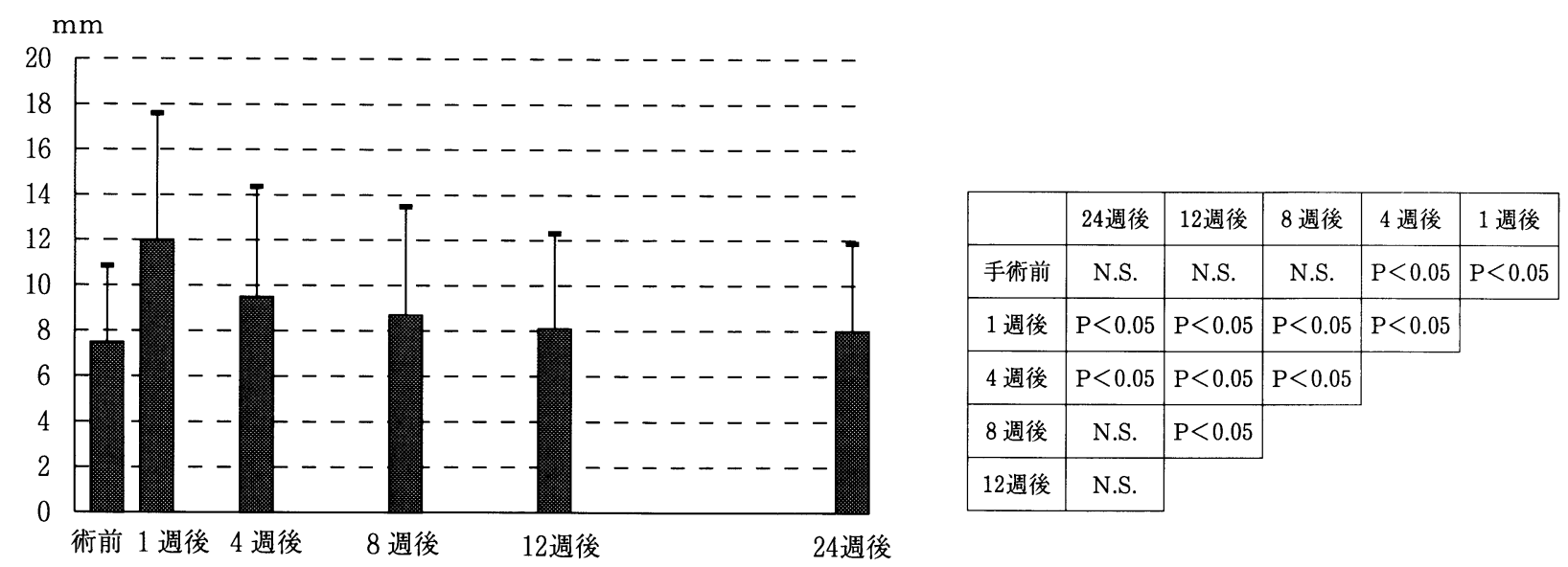

図 $32 \mathrm{PD}$ での平均值の推移

\section{3 . 振動覚検査}

振動覚検査の平均値の経時的変化を観察したところ, 手 術前が75.5 $\pm 18.3 \times 10^{-2} \mathrm{G}$ で, 手術 $1,4,8,12,24$ 週後

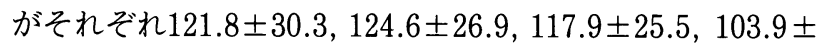
$20.8,96.7 \pm 18.2 \times 10^{-2} \mathrm{G}$ であった. 術前の值に比べて手
術 $1,4,8,12,24$ 週後ともに統計学的有意差を認めてい た.また手術 1 週後に比べて 4,8 週後では有意差はなく， 12 週後は 8 週後に比べ有意差があったが, 手術 12 週後と 24 週後の間には有意差は認めなかった（図 4 ）.

次に, 各週ごとの散布度のヒストグラムを作成し, 経時 


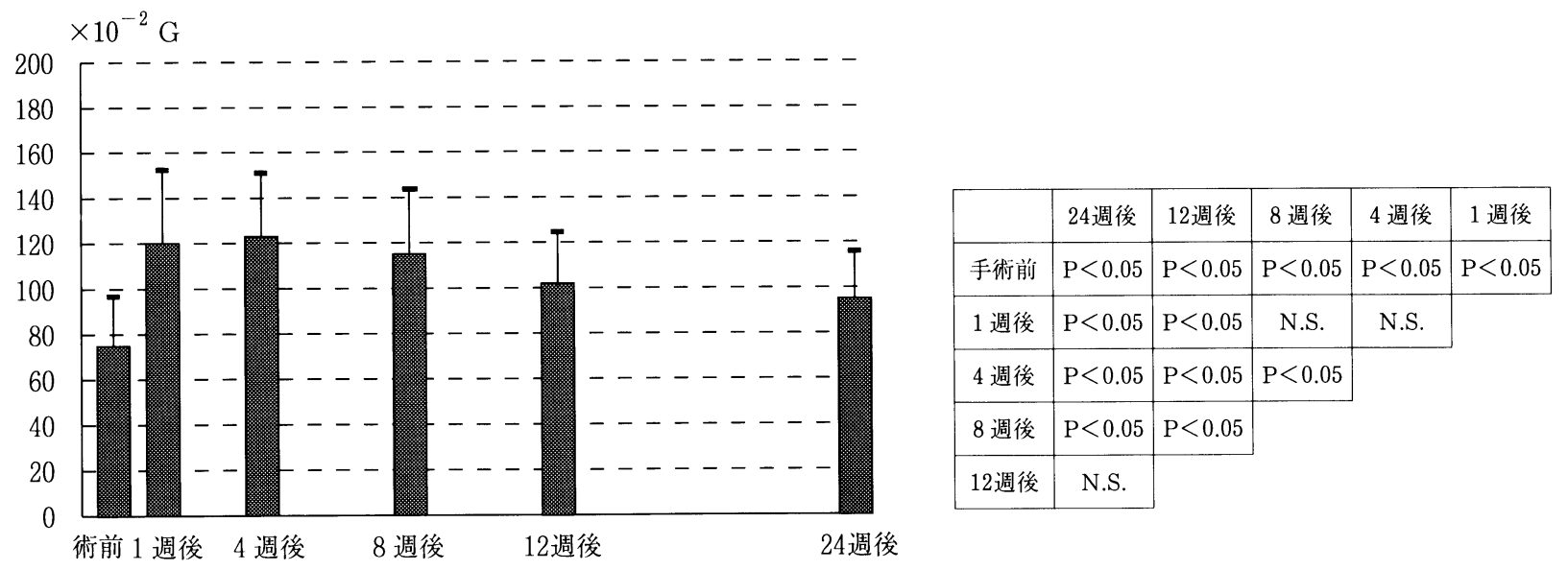

図 4 振動覚検査での平均値の推移
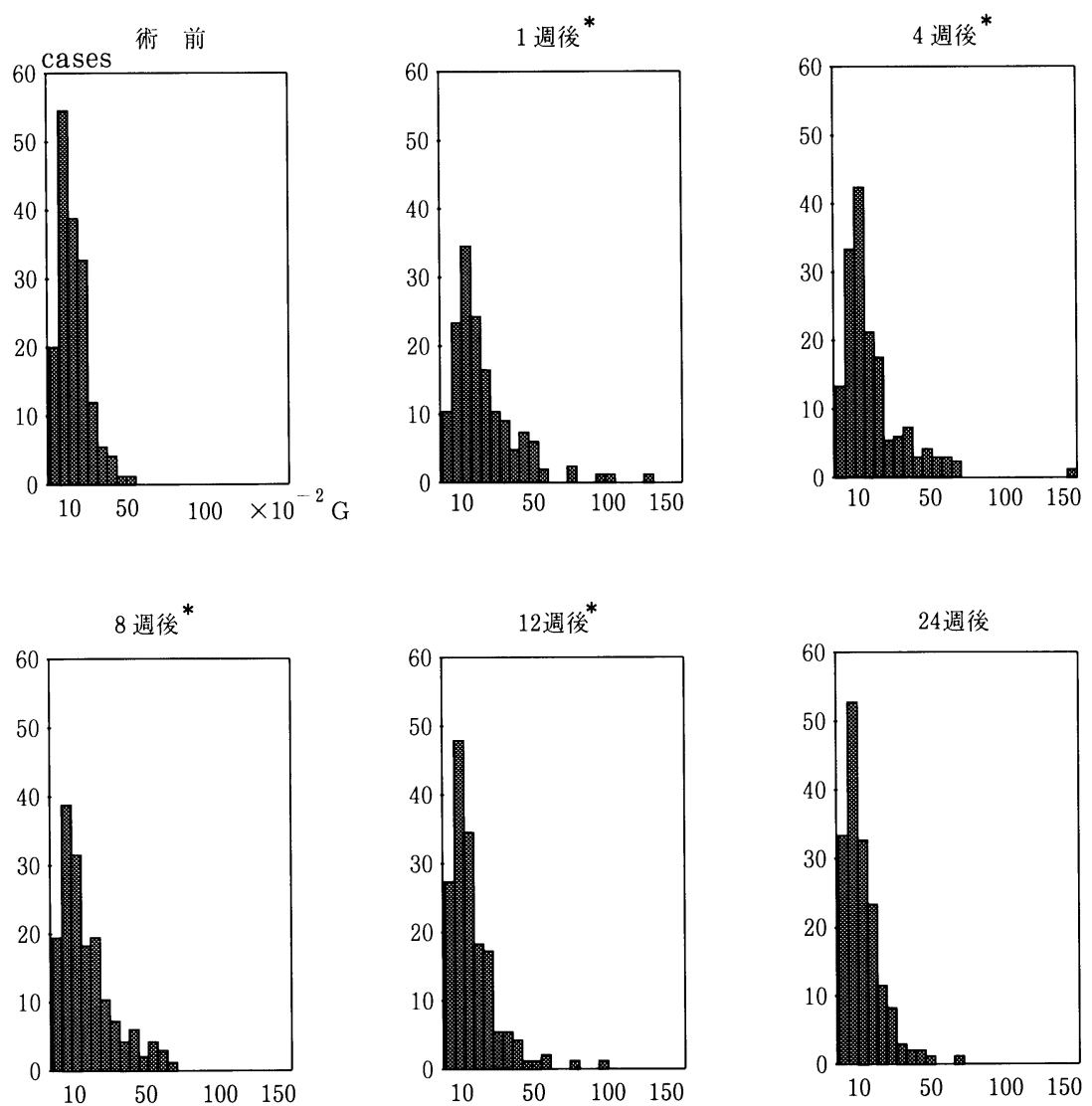

図 5 振動覚検査での散布度の経時的変化

$(*: \mathrm{p}<0.05)$

的な推移を観察した. 術前を基準にすると, 手術 1 週後で 散布度が最も大きく, 以後経時的に散布度は減少し, 手術 2 4週後では術前值に近づいた。この散布度の経時的推移に ついて, 術前を基準とし統計的処理を行ったところ, 手術 1 〜12週後には有意差を認めていたが, 手術 24 週後には有意
差がみられなかった（図 5 )。

なお，振動覚検查で測定不可のものは $19 / 168$ 側（11.3

\%)で, このなかで Level $2 \sim 5$ のものは $12 / 19$ 側 $(63.2$

\%)であった. 


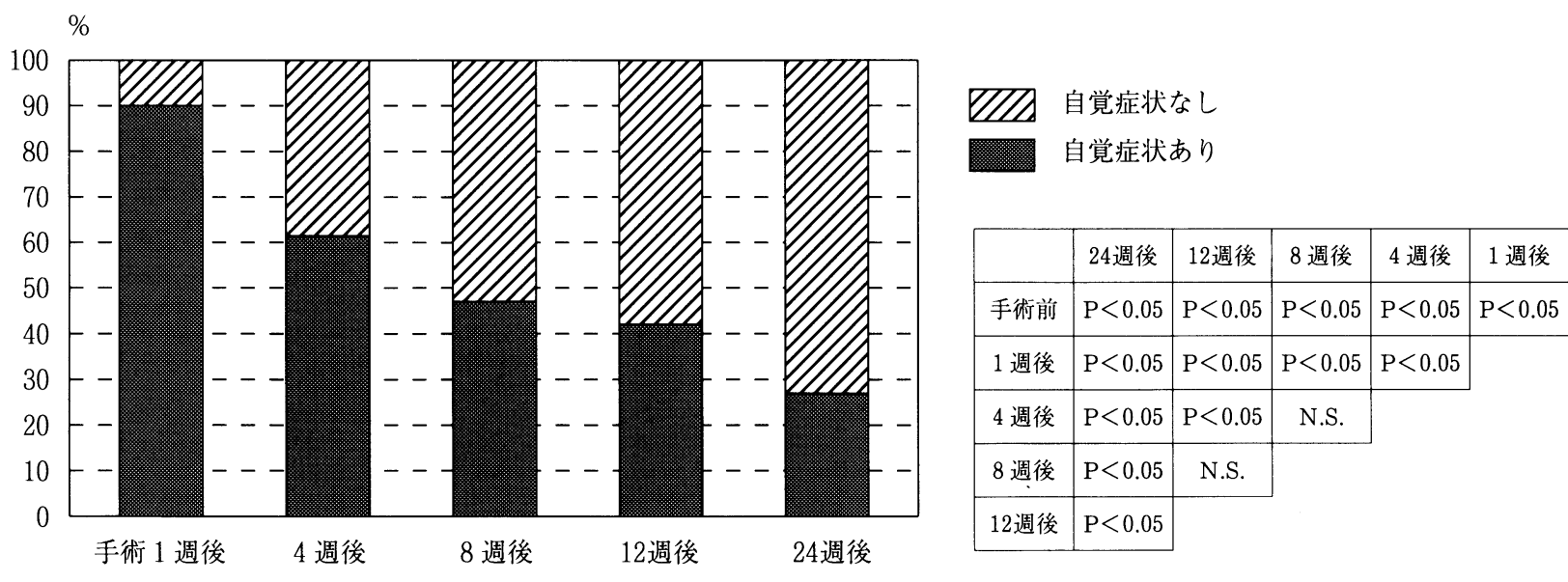

図 6 自覚症状の経時的推移

\section{4 . 自覚症状}

自覚症状の経時的変化を観察したところ，なんらかの自 覚症状を訴えていたものは，手術 1 週後には $89.9 \%, 4$ 週 後には61.3\%，8 週後には $48.2 \%, 12$ 週後には $41.1 \%, 24$ 週 後には $27.4 \%$ であり経時的に明らかな減少が認められた。 手術 4 週後に対し 8 週後では統計学的有意差がなく, 手術 8 週後に対し12週後でも有意差を認めなかったが，手術 12 週後に対し手術24週後には有意差を認めた（図 6 ）.

\section{5 . 自覚症状と検査值との関係}

各検査値を自覚症状の「あり・なし」で分類した際のそ の值の推移を観察した.

各検査とも自覚症状がある場合は自覚症状がない場合に 比べ, 明らかに高い闇值を示していた．また，自覚症状があ る場合には手術24週後でも術前値までの回復を認めなかっ た (図 $7 \mathrm{a} \sim \mathrm{c}$ ).

\section{6 . 振動覚検査での散布度と自覚症状との関係}

今回の結果から, 手術 1 週後に SW test での最小值であ る1.65が触知可能のものが101/168側 $(60.1 \%)$ であった. この 101 側のなかで自覚症状の訴えのないものは 17 側 $(16.8 \%)$ と少なく,それ以外の 84 側 $(83.2 \%)$ は何らかの 自覚症状を訴えていた。そこで, SW testで最小值の 1.65 を触知可能であったものについて, 振動覚検査の散布度と 自覚症状の関係について検索を行った（図 8 ). 散布度の 「大・小」と，自覚症状の「あり・なし」について $\chi^{2}$ 検定 を行ったところ, 手術 $1 ， 4 ， 8,12$ 週後ともに有意差があ り, 手術24週後になって有意差がなくなった。なお，散布度 の大, 小を分けるのにあたっては術前の散布度の中央值を 基準とし, 中央値16.2より大きいものを散布度大, 小さい ものを散布度小とした。

\section{考}

察

\section{1. 感覚と受容器について}

感覚の種類とそれに対応する受容器は, 従来よりさまざ まな考え方がある ${ }^{15 \sim 22,36 ~ 42)}$. 遅順応性受容器としては, Merkel 触盤, Ruffini 小体, 毛囊終末, 自由神経終末など があり, 速順応性受容器には Pacini 小体, Meissner 小体, Golgi-Mazzoni 小体, Pacini 様小体, 自由神経終末などが ある ${ }^{15,36,40)}$. これらの受容器について Dellon（1981）は， 手指においては Merkel 触盤は遅順応性感覚単位のなかの 静的触覚や圧覚を知覚するもの, Pacini 小体と Meissner 小体は速順応性感覚単位で動的触覚や振動覚を知覚するも のであると述べている15).そして，手指における機能的な 知覚検査を行うにあたり, 触覚を静的に接触したものを知 覚する静的触覚と, 瞬間的な動きの情報を認知する動的触 覚に分類し，それぞれに対応した検査を行う必要があると 述べている15).

オトガイ神経支配領域においてもこのような種々の受容 器の存在を確認したとの報告があるが，ヒトにおいて，主 として下唇とオトガイ部皮膚に存在するのは, 静的触覚の 受容器としては Merkel 触盤, Ruffini 小体, 毛囊終末, 自 由神経終末であり，動的触覚の受容器としては Meissner 小体, Golgi-Mazzoni 小体などであるといわれている ${ }^{37 \sim 40)}$. オトガイ神経領域の感覚は特に摂食, 会話に際して大きな 機能を果たしている。したがって，静的触覚と動的触覚を 対象とする機能的な検査を行う必要があると考えた.

\section{2 . 静的触覚について}

静的触覚の検査法である SW testでは, 手術 4 週後には 術前値に比べて有意差がなくなり，特に振動覚検査に比較 して回復が速いという傾向であった. Karasらによると 


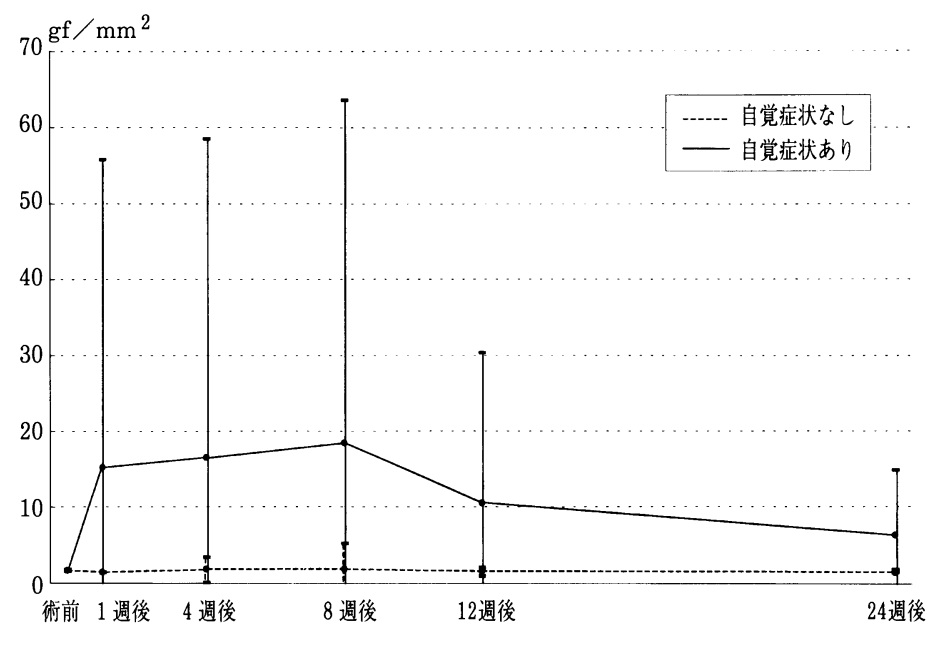

a 自覚症状と SW test との関係

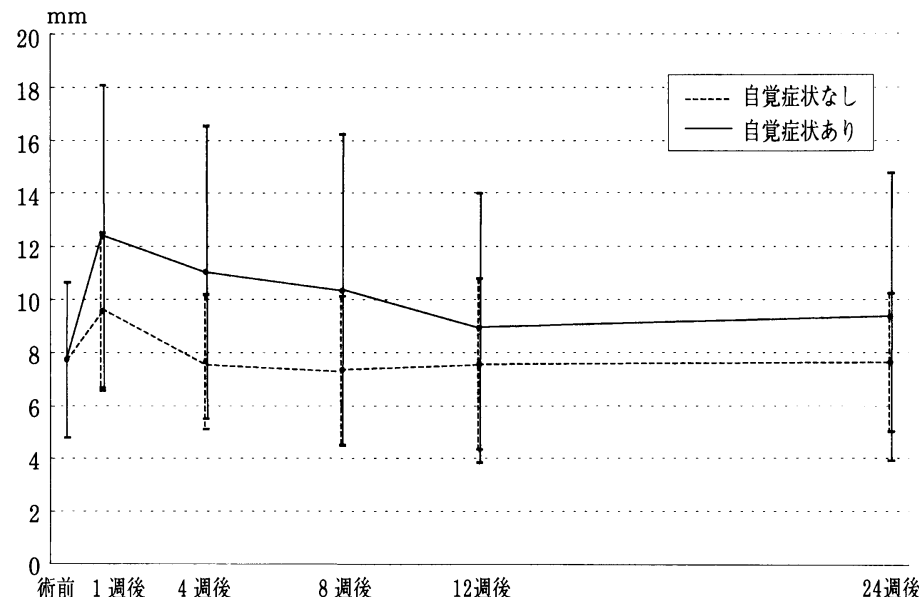

b 自覚症状と $2 \mathrm{PD}$ との関係

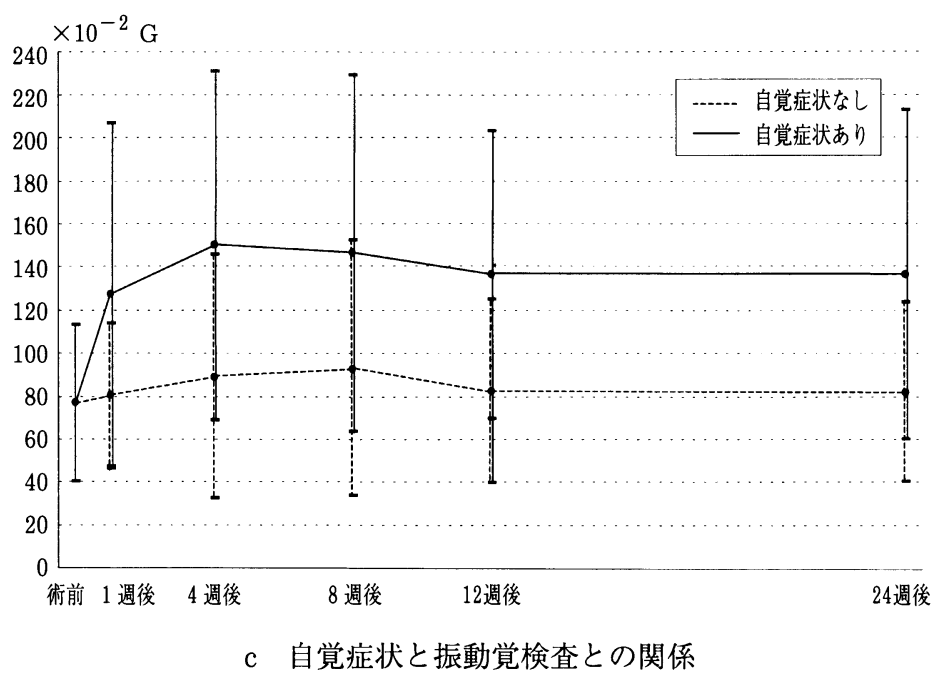




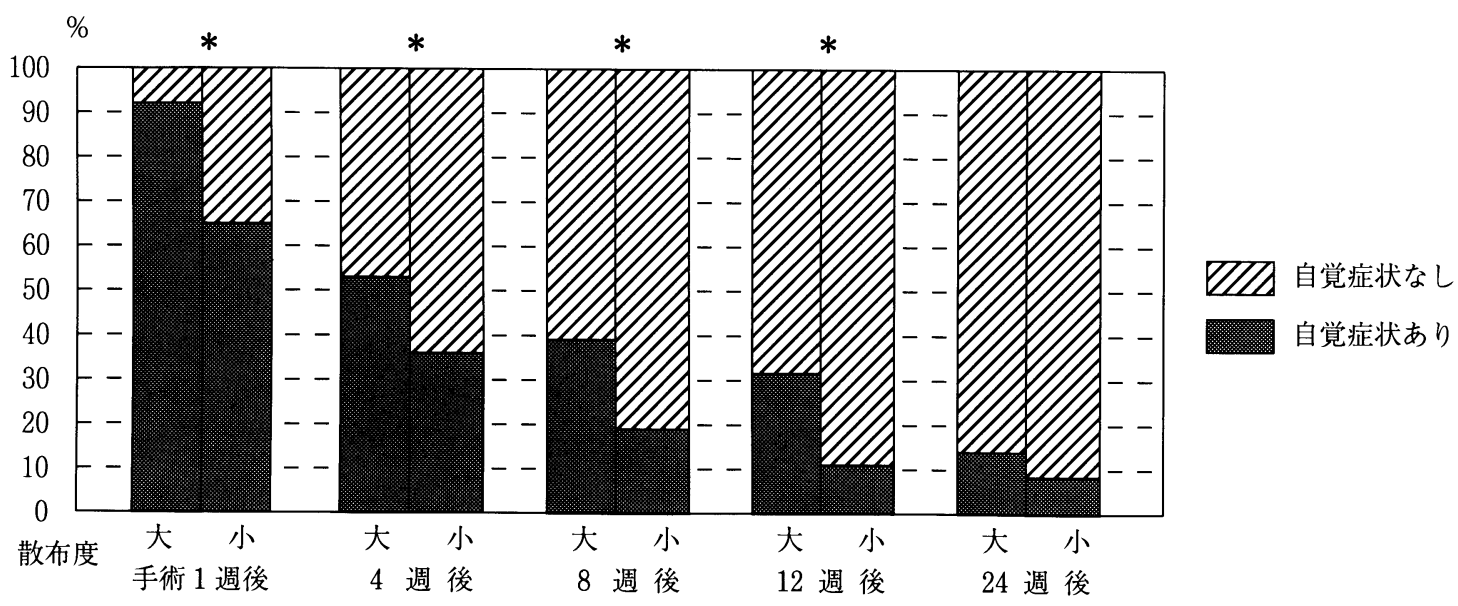

図 8 振動覚検査での散布度と自覚症状の関係

$(*: \mathrm{p}<0.05)$

SW test は手術 4 ～12週後に回復すると述べており ${ }^{13)}$, 妹 尾らも SW test は手術 1 ～ 2 か月後で術前の状態に近づき 振動覚検査に比べ回復が速いと述べている7). SW test は 感覚のなかでも障害からの回復が速いといわれている細い 神経線維の機能を検出しているものと考えられており15), これらの神経線維がある程度回復すれば SW testではほ とんど正常值を示すのではないかと思われた．また手指で はSW testは Merkel 触盤に関係しているといわれてい $ろ^{16,25)}$. Munger ら, Lacour らによると, ヒトでは Merkel 触盤は下唇に多く，オトガイ部皮虐では Ruffini 小体や自 由神経終末, 毛囊終末などが多いと報告している37〜39). オ トガイ神経支配領域においては，これらが複合的に関係し ているものと考えられた。

ところで, 手術 1 週後に SW test で最小值の 1.65 が触知 可能であったものが $101 / 137$ 側 $(73.7 \%)$ と過半数を占め ていた.これらのうちで自覚症状の訴えのなかったものは 17側 $(16.8 \%)$ だけで, ほとんどのものが何らかの自覚症 状を訴えていた. 次いで, Level 2 以上ではすべてのもの が自覚症状を訴えていた. 今回の結果から, SW test は触 覚が有るか否かというレベルの検査であって, 神経線維に axonotmesis や neurotmesis のような高度な損傷が生じて いる場合に, 障害程度や回復状態を把握するのに有効であ ると考えられた. したがって本法は, 軽度な知覚障害や静 的触覚以外の障害の検出には不向きであり, 他の検査法を 併用する必要性があると思われた。

次に, $2 \mathrm{PD}$ では手術 8 週後には有意差がなくなり，ほぼ 術前の状態に回復していた。 $2 \mathrm{PD}$ の回復については Karas ら手術 $4 \sim 12$ 週後で ${ }^{13)}$, Jones らも手術 $1 \sim 2$ か月 後で術前の状態に回復すると述べており ${ }^{14)}$, 今回の結果も 従来までの報告とほぼ同様の結果であった.この検査にお
ける回復状態は, SW test と同様に細い神経線維の回復に 関係しているものと考えられており ${ }^{15)}$ ，また対象とする受 容器もSW test と同様に Merkel 触盤や Ruffini 小体, 自 由神経終末, 毛囊終末などが複合的に関係していると考え られる15,37 39). そのために SW testの結果と同じく，振動 覚検査に比べると回復が速い検査結果が出る傾向にあった ものと考えられた. しかし，SW test と同様に静的触覚の 観察をしているにもかかわらず, SW testより少し回復が 遅れるのは，2PDで対象としているのは神経支配分布密 度であるためであろう15,17,18).

SW test や 2 PD は口唇周囲の知覚検査としては最も広 く行われている ${ }^{2 \sim 7,12 \sim 14)}$. Takasaki らによると SW test は定量的かつ経時的に検査できるとしている ${ }^{3)}$. 今回の結

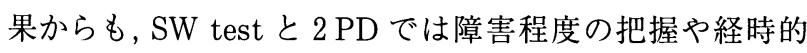
変化の観察には有効であると考えられた。しかしながら， これらは触覚のうちの静的触覚のみを観察しているため, 特に障害が軽度の場合や障害の回復が間近な場合には自覚 症状と対応しないという久点があることが明らかになっ た。

\section{3 . 動的触覚について}

振動覚は速順応性感覚単位に属する動的触覚の 1 つであ る $^{15)}$. 振動覚の研究は, 音叉による振動覚検査が主流で あったが, やがて電動式振動覚計に移行し20,21), その後さ まざまな改良が加えられ, 電動式振動覚計のなかでも実際 の振動覚に最も近いといわれている ${ }^{30,33)}$. 加速度表示の SMV- 5 が鈴木・松岡らによって開発された ${ }^{29-32)}$. 著者ら は以前より SMV-5 をオトガイ神経支配領域の知覚障害の 検出に使用し，その有用性について検討してきた ${ }^{2)}$.

今回の検査結果から SMV- 5 による検查值の平均値の推 
移をみてみると, 手術 24 週後でも術前状態までの回復の傾 向が認められなかった。 また散布度では手術24週後に回復 傾向が認められた。この結果より，振動覚は静的触覚の検 査に比べて回復が遅いという傾向であった. 妹尾らは電圧 を測定する Bio Thesio meter (Bio-medical Instrument 社製）を用いて下顎枝矢状分割法術後のオトガイ部の振動 覚を測定し, SW test P 2 PD に比べ振動覚は回復が遅れ ると報告しており 7 ), 著者と同様の結果であった。これに 対して手指においては, 動的触覚は静的触覚に比べ回復が 速いと Dellon は述べている ${ }^{15)}$. 手指での振動覚の受容器 はPacini 小体といわれているが15 21), Pacini 小体は手掌 や足底の皮下組織や骨膜などに多く, 口唇においてはほと んどみられないといわれている21,41).小泉は，ヒトの口唇 において Meissner 小体を確認しており ${ }^{42)}$, さらに Halata らはヒトの赤唇部では Meissner 小体や Golgi-Mazzoni 小 体, simple corpuscles が認められると述べている ${ }^{38)}$.した がって口唇の振動覚は, Meissner 小体を主体とし,さらに Golgi-Mazzoni 小体, simple corpuscles などが関与してい ると考えられるため, 静的触覚に比べて回復が遅いという 手指とは異なった回復の形成をとるものと考えられた。し かしながら, SMV- 5 は軽度な知覚障害の検出には有効で あるが, 知覚障害が高度な場合には閯值測定の信頼度が下 がるといわれている29-31). 今回の研究でも, SW test で Level $2 \sim 5$ の中等度から高度の知覚障害が検出されてい た場合には，振動覚闇值が最大表示閾を超えて測定不可の ものが多かった. SMV- 5 による振動覚検査は, 静的触覚を 対象とする検査では障害が検出されないのに自覚症状を訴 えているような障害程度が比較的軽度の場合に, その知覚 障害の程度や回復状態を把握するのに有効であることが示 唆された。

\section{4. 自覚症状との対比}

自覚症状は, 主観的なものであり, 定量的に観察するこ とは難しいといわれている6，7). 従来から下顎枝矢状分割 法術後における知覚障害で, 自覚症状については一部 に visual analogue scaleを使ったものがみられるが9), ほとんどのものは自覚症状の有無の判定にとどまってい $ろ^{6 \sim 8,14)}$.

知覚神経損傷後の回復過程における自覚症状を徵候学的 にみると, 全く感覚のない知覚脱失 (anesthesia) から, 刺 激を加えなくてもピリピリする異感覚 (dysesthesia), 刺 激を加えるとピリピリとした不快感が生ずる錯感覚 (paresthesia), しびれたような重い感じのする知覚鈍麻 (hypesthesia) を経て通常の感覚に回復するといわれてい る35). 今回はこれらの症状のいずれかを有するものを「自 覚症状あり」, 全く認めないものを「自覚症状なし」とし
た.今回の結果から, 自覚症状の訴えは経時的に減少する が，手術 24 週後でも $27.4 \%$ \%のに認めていた. また，手術 1 週後に対しては各週ともに回復傾向が認められたが，手 術 4 週後から12週後にかけてはあまり変化がなかった。し かし, 手術12〜24週後にかけては回復傾向が認められた。 このように自覚症状の経時的推移は振動覚検査における回 復状態とほぼ一致していた。

従来, 患者が自覚症状を訴えていても検査上では明らか な障害が認められないことから 6,7), これがトラブルの原 因となったことも多かった. 今回の調査では, SW testで 最小值の1.65を示しているにもかかわらず, 自覚症状を訴 えている場合が多くみられた。このような場合, 振動覚検 査での散布度が大きくなる傾向があった. 反対に自覚症状 が消失してきた際には散布度が小さくなり, 術前と比べて 有意差がなくなった。つまり，振動覚検査を併用したこと で静的触覚検查だけでは見逃される可能性の高い, 動的触 覚検査で異常を示す感覚の検出が可能であると考えられ た。

今回の結果から, 知覚障害が高度の場合には静的触覚を 対象とした SW test や $2 \mathrm{PD}$ の検査結果と自覚症状とが一 致していたが, 動的触覚を対象とした振動覚検査では障害 の検出ができなかった. 反対に, 軽度の障害では SW test や 2 PD では障害が検出されず, 自覚症状と一致していな かったが, 振動覚検査では障害が検出され自覚症状に近い 検査結果が得られた. さらに, 測定時の散布度の大小を確 認することで, 知覚障害の消失時期の推定を行うことがで きるのではないかと思われた。

結 語

下顎枝矢状分割法術後の合併症のなかで, 最も頻度の高 いオトガイ神経支配領域の知覚障害について, 経時的かつ 定量的な観察を行った。

1. 静的触覚を観察する検査のうち, SW testでは手術 4 週後に, $2 \mathrm{PD}$ では手術 8 週後には術前值との有意差がな くなった.

2. 動的触覚を観察する検査である振動覚検査では，手 術 24 週後でも術前值との有意差が有り, 散布度では手術 24 週後に術前との有意差がなくなった。つまり，動的触覚は 静的触覚に比べて回復が遅い傾向であった.

3 . 自覚症状については, 手術 24 週後に回復傾向が認め られ，振動覚検査での経時的変化と傾向が類似していた.

4. SW testで最小值を示しているにもかかわらず自覚 症状を訴えているものが $83.2 \% に$ 認められた。また，この ような軽度の障害の場合には自覚症状と散布度の間に有意 差が認められた. 静的触覚の検査では障害程度や経時的変 
化の観察には有効であるが, 軽度の障害がある場合には動 的触覚の検査を併用する必要があった。

5 . 知覚障害を正しく把握するためには, 異なった感覚 単位を対象とする複数の検査を組み合わせる必要性が示唆 された。

稿を終るに臨み, 統計処理に関して御指導を頂いた本学数 学科菅野隆三教授に御礼申し上げます.また, 種々御協力いた だきました教室員諸兄に心から感謝の意を表します。

\section{参 考 文 献}

1）飯塚忠彦：下顎枝矢状分割法。口口外誌 31：129512981985

2）藤川真紀, 野間弘康，他：SMV- 5 型振動覚計によ る下顎枝矢状分割法術後のオトガイ神経知覚障害の 検出. 日口外誌 46: 533-535 2000.

3) Takasaki, Y., Noma, H., et al.: A clinical analysis of the recovery from sensory disturbance after sagittal splitting ramus osteotomy using a Semmes-Weinstein pressure aesthesiometer. Bull. Tokyo dent. Coll. 39: 189-197 1998.

4）高崎義人, 野間弘康, 他: 下顎枝矢状分割法術後の オトガイ神経知覚検査に関する臨床的研究一第 1 報 SW 知覚テスターを用いた検査方法と報告様式の検 討一。回顎変形誌 10: 290-299 2000.

5）佐々木研一, 正木口立, 他：下顎骨変形弪手術後に おける下歯槽神経麻㾝の回復過程に関する実験的研 究. 日口外誌 32: 1139-1149 1986.

6）小林明子：顔面皮䖉感覚に及ぼす顎矯正手術の影 響一新検查法による解析一。口病誌 63: 131-152 1996.

7）妹尾明寛, 熊澤康雄, 他：顎矯正手術の下顎枝矢状 分割法における術後オトガイ領域知覚異常の経時的 変化に関する研究. 歯学 83: 190-212 1995.

8）鍛治昌孝, 大橋 靖, 他：下顎枝矢状分割術後の長 期下唇知覚麻痺に関する研究一第 1 報 : 多変量解析 による諸因子の検討一。新潟歯学会誌 28: 1-6 1998.

9）鍛治昌孝, 大橋 靖, 他: 下顎枝矢状分割術後の長 期下唇知覚麻痺に関する研究一第 2 報 : CT による 下顎管の位置の検討一。新潟歯学会誌 28: 7-13 1998.

10) Westermark, A., Bystedt, H., et al.: Inferior alveolar nerve function after mandibular osteotomies. Br J Oral Maxillofac Surg 36: 425-428 1998.

11) Westermark, A., Bystedt, H., et al: Inferior alveolar nerve function after sagittal split osteotomy of the mandible: correlation with degree of intraoperative nerve encounter and other variables in 496 operations. Br J Oral Maxillofac Surg 36: 429-433 1998.

12) Josephina, G.P., Smeele, l.E., et al.: Is shortterm neurosensory testing after removal of mandibular third molars efficacious? Oral Surg Oral Med Oral Pathol Oral Radiol Endod 85: 366-370 1998.

13) Karas, N.D., Boyd, S.B., et al.: Recovery of neurosensory function following orthognathic surgery. J Oral Maxillofac Surg 48: 124-134 1990.

14) Jones, D.L., Wolford, L.M., et al.: Comparison of methods to assess neourosensory alterations following orthognathic surgery. Int $\mathrm{J}$ Adult Orthodon Orthognath Surg 5: 35-42 1990.

15) Dellon, A.L.: Evaliation of sensibility and reeducation of sensation in the hand. 1st Ed, The Williams and Wilkins company, Boltimore, 1981, p 3 -192.

16）伊藤 理, 秦 維郎, 他：正常成人日本人の顔面 · 頸部における知覚. 日形会誌 17: 742-749 1997.

17) Kesarwani, A., Antonyshyn, O., et al.: Facial sensibility testing in the normal and posttraumatic population. Annals of Plastic Surgery 22: 416-425 1989.

18) Posnick, J.C., Zimbler, A.G., et al: Normal cutaneous sensibility of the face. Plast Reconrt Surg 86: 429-435 1990.

19）高木健太郎：皮虐感覚. 勝木保次編集; 生理学大系 VI 感覚の生理学. 第 2 編, 医学書院, 東京, 1967, 533-561頁.

20）佐藤昌康 : 振動感覚. 勝木保次編集 ; 生理学大系 VI 感覚の生理学. 第 3 編, 医学書院, 東京, 1967, 615629頁.

21）青木 藩：感覚の生理学. 田崎京二, 小川哲朗編 集 ; 新生理学体系. 第 1 版, 医学書院, 東京, 1989 , 290-309頁.

22）岩堀修明 : 神経解剖学. 第 1 版, 金芳堂, 京都, 1998 , 251-273頁.

23) Bell, J.A.: Sensibility evaluation. In Rehabilitation of the Hand. 1st Ed, CV Mosby, St Louis, 1978, p273-291.

24) Levin, S.B.S., Pesrsall, G.Sc.D., et al.: Von Frey's method of measuring pressure sensibility in the hand: An engineering analysis of the Weinstein-Semmes pressure aesthesiometer. J Hand Surg 3: 211-216 1978.

25) Werner, J.L. and Omer, G.E.: Evaluating cutaneous pressure sensation of the hand. J. Occup. Ther. 24: 347-356 1970.

26）高崎義人, 野間弘康 : 神経損傷後の外科的処置. 歯 科医療 10: 39-53 1996 .

27）野間弘康 : 術後神経麻痺の臨床. 日本歯科医師会雑 誌 46: 850-859 1993.

28）小杉憲吾, 阿部伸一, 他 : オトガイ神経の走行形態 に関する解剖学的研究ーシリコン含浸標本を用いた 三次元的観察一. Jpn J Oral Biol 42: 67-78 2000.

29）鈴木吉彦：糖尿病性神経障害における神経測定機器 の開発について. 厚生省糖尿病調査研究報告書: 583-587 1990.

30）鈴木吉彦, 松岡健平 : 新型振動覚計 (SMV-0～2 ) の作成経緯. Diabetes Journal 17: 44-47 1989. 
31）鈴木吉彦, 松岡健平 : 新型振動覚計 (SMV- 5 ) の 作成経緯（第 2 報）. Therapeutic Research 12: 5775841991.

32）鈴木吉彦：糖尿病患者の振動覚検査. Diabetes Frontier 2: 445-454 1991.

33）内藤 寛, 葛原茂樹：振動覚計（SMV-5) を用い た感覚障害の客観的評価の試み一振動覚閾値と感覚 神経伝導速度との相関について一。神経内科 41: 299-301 1994

34）大西晃生, 八幡澄和, 他：3つの機種（Vibration II，TM-31A およびSMV-5 ）による振動覚弁別閥 值評価の比較一信頼性, 年齢との相関および各機種 による測定值の相関関係一. JUOEH（産業医科大 学雑誌) 16: 61-70 1994 .

35）松田康男：下歯槽神経活動電位に対する神経損傷の 影響 第 2 編 臨床的研究. 歯科学報 80: 1591-1611 1980.

36）黑住一昌：皮虐感覚器の微細構造. 神経研究の進歩 25: 456-481 1981.
37) Munger, B.L. and Halata, Z.: The sensory innervation of primate facial skin. I. Hairy Skin. Brain Res Rev 5: 45-80 1983.

38) Halata, Z. and Munger, B.L.: The sensory innervation of primate facial skin. II . Vermillion Border and Mucosa of Lip. Brain Res Rev 5: 81-107 1983.

39) Lacour, J.P., Dubois, D., et al: Anatomical mapping of Merkel cells in normal human adult epidermis. Br J Dermatol 125: 535-542 1991.

40）鈴木 隆 : 顎・口腔 - 顔面の体性感覚. 中村嘉男, 森本俊文編集; 基礎歯科生理学. 第 3 版，医歯薬出 版, 東京, 1998, 255-276頁.

41) Johansson, R.S., Trulsson, M. et al.: Mechanoreceptor activity from the human face and oral mucosa. Exp Brain Res 72: 204-208 1988.

42）小泉 良：ヒト上口唇におけるマイスネル小体の発 達について一電顕的・組織化学的検索一. 日形会誌 11: 119-133 1991. 